\title{
PARTICLES ASSOCIATION STUDY OF A BORATE SAMPLE FROM SIJES DISTRICT, ARGENTINA
}

\section{ESTUDIO DE LA ASOCIACIÓN DE PARTÍCULAS DE UNA MUESTRA DE BORATOS DEL DISTRITO SIJES, ARGENTINA}

\author{
Rosa M. Torres Sánchez ${ }^{1} \quad$ Lilian E. Mattenella ${ }^{2}$ \\ Recibido 13 de marzo de 2006, aceptado 11 de septiembre de 2006 \\ Received: March 13, 2006 Accepted: September 11, 2006
}

\begin{abstract}
RESUMEN
La ampliación de los mercados que utilizan borato, principalmente el de la producción de fritas cerámicas, ha llevado a los productores de dicho mineral a mejorar su competitividad a través de su concentración y/o purificación tanto por medio de su molienda así como mediante la caracterización de minerales con alto contenido en $\mathrm{B}_{2} \mathrm{O}_{3}$.

En los minerales provenientes de Sijes, Provincia de Salta, Argentina, se han identificado principalmente colemanita e hidroboracita, con $50.84 \%$ y $50.54 \%$ en $\mathrm{B}_{2} \mathrm{O}_{3}$, respectivamente, lo cual los hace potencialmente interesantes para su utilización industrial. La técnica de purificación por deslamado en hidrociclón para purificar $\mathrm{B}_{2} \mathrm{O}_{3}$, permite la disminución de impurezas indeseables para la comercialización del borato (óxidos principalmente férricos, cloruros y sulfatos). Esta técnica de purificación no sólo elimina las lamas presentes sino que además genera poros, mediante la disminución de la superficie específica de las partículas. En este trabajo se analizan dos muestras obtenidas en diferentes etapas de purificación: después y previo al deslamado. Los análisis químicos y mineralógicos (método de Rietveld) de ambas muestras indican la disminución del porcentaje de colemanita, esmectita e illita en la muestra deslamada, con un pequeño aumento relativo del porcentaje de hidroboracita. Los parámetros de carga eléctrica superficial (PZC e IEP) coinciden con las observaciones de microscopía electrónica, revelando asociaciones entre los minerales sólo en la muestra sin deslamar.
\end{abstract}

Palabras clave: Minerales industriales, boratos, punto isoeléctrico, punto de cero cargas, análisis cuantitativo por el método de Rietveld.

\section{ABSTRACT}

The increasing range of borate uses, mainly in the ceramic frit market, led borate producers to improve competitiveness through concentration and/or purification steps in the mill circuit as well as in the characterization of high content $\mathrm{B}_{2} \mathrm{O}_{3}$ minerals.

Minerals coming from Sijes, Salta Province, Argentina, mainly identified as colemanite and hydroboracite, with 50.84\% and 50.54\% $\mathrm{B}_{2} \mathrm{O}_{3}$ respectively, are potentially interesting from an industrial point of view. The desliming purification technique in hydrocyclones used to upgrade $\mathrm{B}_{2} \mathrm{O}_{3}$ and downgrade undesirable impurities to the borate market (Rietveld method) mainly iron oxides, chlorides and sulphates) not only eliminates slimes but it also generates pores, through a decrease of the specific surface of the particles. Two samples under different purification steps were analyzed: deslimed and without desliming. The chemical and mineralogical analyses of both samples indicate a decreasing percentage of colemanite, smectite and illite in the deslimed sample with a small increase of hydroboracite. The parameters of surface electric charge (PZC and IEP) match the observations made with the electronic microscopy, reveal mineral associations only in the sample without desliming.

Keywords: Industrial minerals, borates, isoelectric point, point of zero charges, quantitative Rietveld analysis.

1 CETMIC. Cno. Centenario y 506, CC 49-1897 M.B. Gonnet, Argentina. E-mail: rosats@netverk.com.ar

2 INBEMI. Fac. de Ingeniería, INIQUI, Av. Bolivia 5150-4400 Salta, Argentina. E-mail: lematten@unsa.edu.ar 


\section{INTRODUCTION}

The borates from South American Puna: sodium (tincal), calcium (colemanite and inyoite), sodium and calcium (ulexite) and calcium and magnesium (hydroboracite) have been processed [1-5] for recovering $\mathrm{B}_{2} \mathrm{O}_{3}$. The use of borates as fluxes, glass formers and glazes has been extended to the ceramic frit market, mainly in Europe leading the technology of frit [6-7].

Among the Puna borates, colemanite and hydroboracite, contain 50.84 and $50.55 \% \mathrm{~B}_{2} \mathrm{O}_{3}$ respectively, can be upgraded to fulfill the technical regulations of the market. The upgrading $\mathrm{B}_{2} \mathrm{O}_{3}$ techniques usually involve gravity separation, size classification, magnetic separation and froth flotation. Thermal treatment is another suitable upgrading method, which leads to a less hydrated crystalline form, but also the impurities are upgraded.

The separation of colemanite and hydroboracite from the gangue on preconcetrate sample was studied by several methods, including surface charge properties of the particles. It is selective flotation with anionic and cationic collectors, selective coagulation, etc. [8-12] reaching grades of purity about $80 \%$ in hydroboracite.

Both minerals feature with some similar physical and physicochemical properties [12] were suspected of association that difficult higher grades of purification [9]. They are monoclinic, white solids, diamagnetic, specific weight of colemanite: $2,41 / 2,42 \mathrm{~g} / \mathrm{cm}^{3}$ and 2,17 for hydroboracite, solubility of colemanite $(\mathrm{g} / 100 \mathrm{ml}$ of water, $20^{\circ} \mathrm{C}$ ): 0,16 and 0,20 for hydroboracyte [5].

The present study was performed to characterize a borate sample from Sijes Dictrict, Salta Province, Argentina, obtained from two steps during the mineral dressing, which could help to overcome the technical difficulties found to separate hydroboracite. Bulk and surface techniques were used: XRD and Rietveld methods to identify the mineral composition of both samples, deslimed and without desliming and IEP and PZC determinations for the surface charge characterization (of little use in the minerals interaction field) to determine the association among them.

\section{MATERIALS AND METHODS}

A selected raw material characterized by its high grade in hydroboracite and colemanite, coming from Sijes District, Salta Province, Argentina, was employed in this study.
The preparation of samples involved three stages:

First stage: Preconcentration in the industrial plant by washing in a trommel, and then crushing into minus 1".

Second stage: Crushing in a hammer mill and screening in pilot plant, in several steps:

- Crushing into minus $3 \mathrm{~mm}$ and screening into minus 100 \#.

- The over sizes (coarser than 100 \#) crushed again into minus $1 \mathrm{~mm}$ and screening into 100 \#.

- Oversizes were taken away.

- Blending of undersize (finer than 100 \#).

- Pulping for desliming. A volume of unclassified pulp was identified as Sample 1 (undeslimed sample).

- Hydrocycling for desliming. The overflow was taken away (very fine slimes), and the underflow again deslimed by settling into minus 10 microns. Middling sizes (100\# - $10 \mu$ ) constituted Sample 2.

Hydrocycling has noticeable advantages for boron mineral classification [5]:

- Clays area easily separated by water jets.

- Decreasing of soluble impurities.

- Lower separation sizes (cut point) can be chosen.

Third stage: Hydroboracite and colemanite samples with purity over $95 \%$ were obtained by hand sorting under microscope from Sample 2.

The morphology of particles was observed by scanning electron microscopy (SEM) with Philips SEM 505 equipment. The analyses were performed on gold sputtered powder samples, following the Goldstein and Yakowitz [13) technique.

The mineralogical compositions were carried out by powder XRD using a Philips PW1140/00 diffractometer $\mathrm{Cu} \mathrm{K} \alpha(1.54 \AA)$ radiation, Ni Filter and $40 \mathrm{kV}$ and $20 \mathrm{~mA}$. The quantification of phases was carried out using the Rietveld method [14] and FULLPROF [15] program. The crystallographic data of each phase were extracted from the literature [16]. The quartz present in the samples was used as internal standard taking into account the $2 \theta$ shift by the vertical displacement of the sample and the baseline into the refinement sequence. Later, each phase was refined sequentially: the scale factors, the cell constants, the parameters for width of height half (FWHM) calculation, the coefficients of the peak function (pseudo Voight) and the preferential orientation with the March function. 
Surface area was determined in a Quanta Chrome Autosorb equipment adsorbing $\mathrm{N}_{2}$ on samples dried at $45^{\circ} \mathrm{C}$ for 72 $\mathrm{h}$, using the BET method [17].

The determination of isoelectric point (IEP) was done by the diffusion potential method in $\mathrm{KCl}$ electrolyte [18]. The IEP is the value of $\mathrm{pH}$ graphically determined when the transport number of the cation $\left(\mathrm{t}^{+}\right)$is 0.5 in a diagram of $\mathrm{t}^{+}$against the $\mathrm{pH}$ of the sample. The transport number is obtained from the electromotive force (EMF), originated by the electrolyte ions moving within the charge sample between two different concentrations of the same electrolyte $(\mathrm{KCl})$. EMF measurements were carried out with a Keithley 616 digital electrometer with Metrohm calomel electrodes.

The point of zero charge (PZC) was determined by the titration method [19] in $\mathrm{N}_{2}$ atmosphere and blank subtraction, using a Model 716-Titrino (Metrohm AG, Herisau, Switzerland). $\mathrm{KCl}$ solutions $10^{-1}, 10^{-2}$ and $10^{-3}$ $\mathrm{M}$ were used as supporting electrolytes. Titrations were carried out additioning $0.001 \mathrm{~cm}^{3}$ of $\mathrm{HCl} 0.1 \mathrm{M}$ or $\mathrm{KOH}$ every 5 seconds.

\section{RESULTS}

The XRD qualitative analysis indicates coincidence of crystalline species in samples, 1 and 2. Figure 1 shows the XRD patterns of observed, calculated (obtained by the Rietveld method), the difference between both spectra and the Bragg lines from (in descending order): hydroboracite, colemanite, smectite and illite, identified in the Sample 2.

The difference obtained between the observed and calculated spectra, in the region between 10.8 and $16^{\circ}(2 \theta)$ reveals a low theoretical fit assigned to the presence of crystalline phases in very small quantities that could be hidden by the majority species. The general fit of the spectrum was inside the ranges $\left(\mathrm{R}_{\exp }=15.0\right.$ and $\left.\mathrm{R}_{\text {calc }}=35.0\right)$ found in mineral mixtures [20]. Similar fit was found between observed and calculated spectra for Sample 1 (not shown).
The quantitative analysis of the crystalline phases obtained by Rietveld method, adjusts $100 \%$ to the obtained data. Consequently the decrease found in smectite and colemanite in Sample 2 related to Sample 1 arises a proportional increase of hydroboracite in the first sample. The decrease of the smectite percentage (particle size $<2 \mu \mathrm{m}$ ) is a direct consequence of the desliming in hydrocyclone of Sample 2.

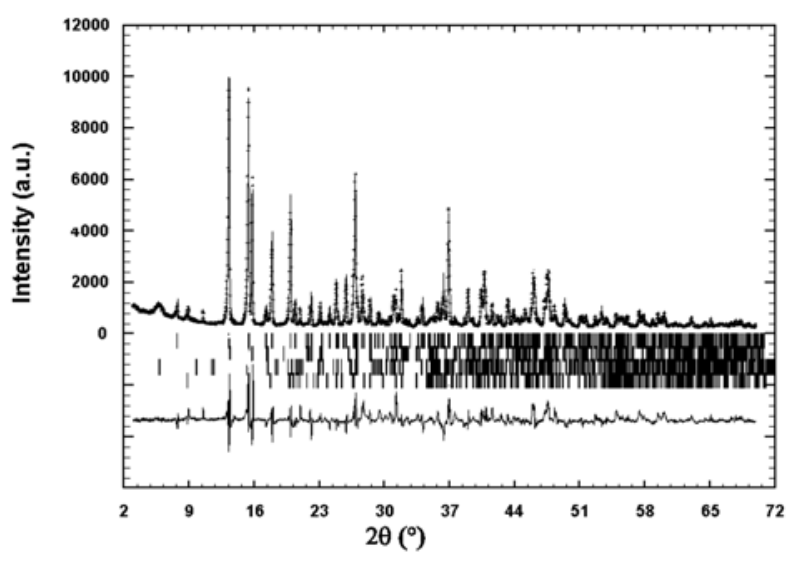

Figure 1. Observed (dotted line) and calculated (solid line) patterns for Sample 2. Bragg position of the species: hydroboracite, colemanite, smectite and illite. The lower curve shows the difference between observed and calculated patterns.

Table 1. Indicates the quantitative analysis data obtained by the Rietveld method for samples 1 and 2 .

\begin{tabular}{|c|c|c|c|c|}
\hline Sample & $\begin{array}{c}\text { Hydroboracite } \\
\mathbf{( \% )}\end{array}$ & $\begin{array}{c}\text { Colemanite } \\
\mathbf{( \% )}\end{array}$ & $\begin{array}{c}\text { Smectite } \\
\mathbf{( \% )}\end{array}$ & $\begin{array}{c}\text { Illite } \\
\mathbf{( \% )}\end{array}$ \\
\hline 1 & 75.0 & 14.6 & 7.4 & 3.0 \\
\hline 2 & 81.1 & 12.1 & 4.0 & 2.8 \\
\hline
\end{tabular}

Table 2 resumes data from $\mathrm{B}_{2} \mathrm{O}_{3}, \mathrm{MgO}$ and $\mathrm{CaO}$ obtained by chemical analysis and specific surface of the Samples 1 and 2 , and the composition of pure hydroboracite and colemanite.

Table 2. Chemical analysis of main oxides and specific surface for Samples 1 and 2, and chemical composition of pure hydroboracite and colemanite.

\begin{tabular}{|c|c|c|c|c|}
\hline Sample & $\mathbf{B}_{\mathbf{2}} \mathbf{O}_{\mathbf{3}} \mathbf{( \% )}$ & $\mathbf{M g O}(\mathbf{\%})$ & $\mathbf{C a O}(\mathbf{\%})$ & Specific surface $\left(\mathbf{m}^{2} \mathbf{/ g}\right)$ \\
\hline 1 & 37.87 & 6.88 & 14.57 & 3.46 \\
\hline 2 & 42.30 & 7.13 & 14.98 & 1.78 \\
\hline Hydroboracite & 50.54 & 9.76 & 13.57 & - \\
\hline Colemanite & 50.84 & - & 27.26 & - \\
\hline
\end{tabular}


The loss of about $6 \%$ of fraction $<10 \mu \mathrm{m}$ (table 1) in Sample 2 related to Sample 1, was similar to the relative percentage difference of oxides content increase of 3.5\% for $\mathrm{CaO}$ and $2.8 \%$ for $\mathrm{MgO}$ respect to the increase of $10.5 \%$ for $\mathrm{B}_{2} \mathrm{O}_{3}$.

The specific surface decreases with hydrocycloning, which also indicates the loss of slimes [21, 22] in Sample 2.

Figure 2 shows the electron microscopy photographs for Sample 1, (A-B), and Sample 2 (C).
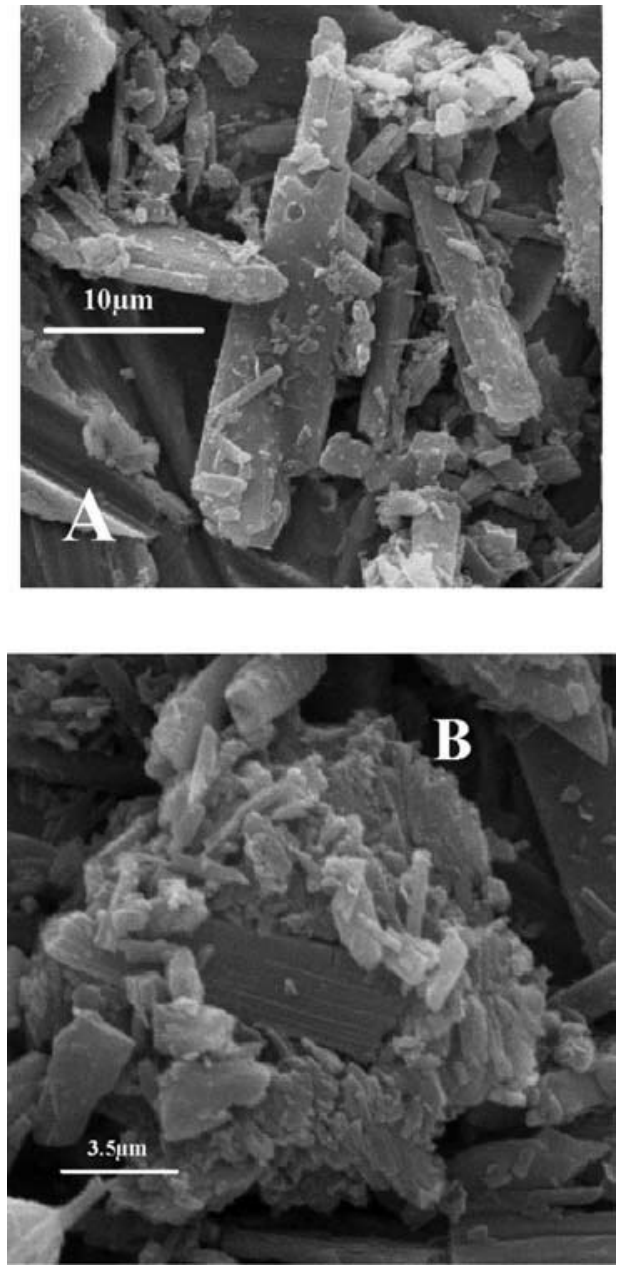

Figure 2. Electron microscopy photographs: (A)-(B) Sample 1, (C) Sample 2.

The electronic microscopy analysis indicates two types of morphologies for the observed particles. The Sample 1 presents lengthened particles, with dimensions around $40 \times 7 \mu \mathrm{m}$, coated with small particles, which could not be analyzed by EDAX (due to the absence of isolated particles). These coating particles would correspond to the slimes previously indicated. The detailed analysis of Sample 1, presented in figure 2 (A and B), allowed detecting groups of particles with morphologies assigned to colemanite and hydroboracite, respectively.

The Sample 2 (figure $2 \mathrm{C}$ ) shows particles of more homogeneous dimensions (similar sides of around $15 \mu \mathrm{m}$ ) and also the presence of coating particles of smaller sizes is evidenced. Associations among particles of Sample 2 were not identified after a statistical scanning.

Determinations of particle surface charge parameters are useful to evaluate if the small particles coating colemanite and hydroboracite particles have electrostatic (Coulombic) bindings (as specific cation/anion adsorption $[23,24]$. It is known that the particle surface charge varies with the $\mathrm{pH}$ of the system and the IEP and the $\mathrm{PZC}$, both determined varying the $\mathrm{pH}$ of the suspension, occurs at the same value of $\mathrm{pH}$ only in the absence of specific adsorption (adsorption for which the adsorption energy differs from the Coulombic energy [25]. Specific ionic adsorption changes both the IEP and the PZC in opposite direction of $\mathrm{pH}$ [26]. The expressions mentioned before are not always used in the same way by different groups of researchers. A brief comment to clarify the topic is added.

The $\mathrm{pH}$ which the electrokinetic potential of a particle is zero is called IEP. IEP of pure samples are determined by microelectrophoresis, being the IEP of colemanite $\mathrm{pH}=10.5$.

No zero of electrokinetic potential was found for hydroboracite [4]. Surface potential of clay particles, i.e. montmorillonite (from smectite mineral) differs only about $10 \mathrm{mV}$ between $\mathrm{pH} 4$ and 10 [27]. No zero of electrokinetic potential can be found when samples are formed by oxides or particle mixtures either. Both obstacles for the IEP determination of Sample 1 and Sample 2 (mixture of hydroboracite and colemanite) are overcome by measuring the transport number $\left(\mathrm{t}^{+}\right)$ at different $\mathrm{pH}$ of sample [18].

Another parameter related to particle surface charge is the PZC; the $\mathrm{pH}$ which the titratable surface charges is zero.

The figure 3 shows the curves of transport number in function of $\mathrm{pH}$ for Sample 1 and Sample 2. 

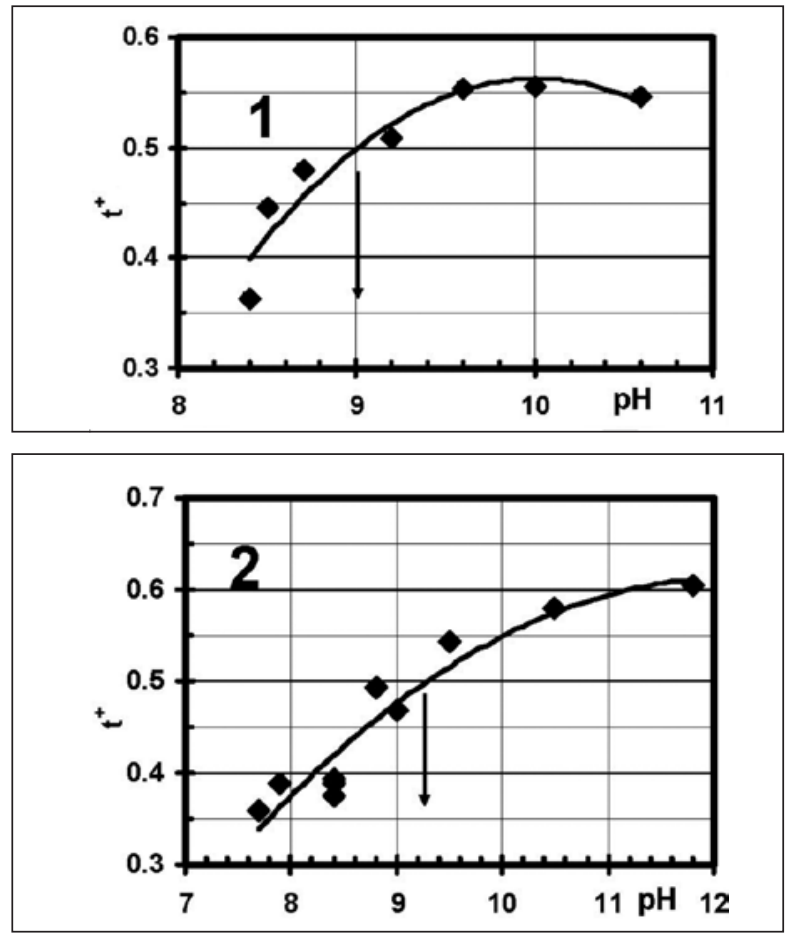

Figure 3. Transport number in function $\mathrm{pH}$ for Samples 1 and 2.The arrow indicates the $\mathrm{pH}$ of IEP.
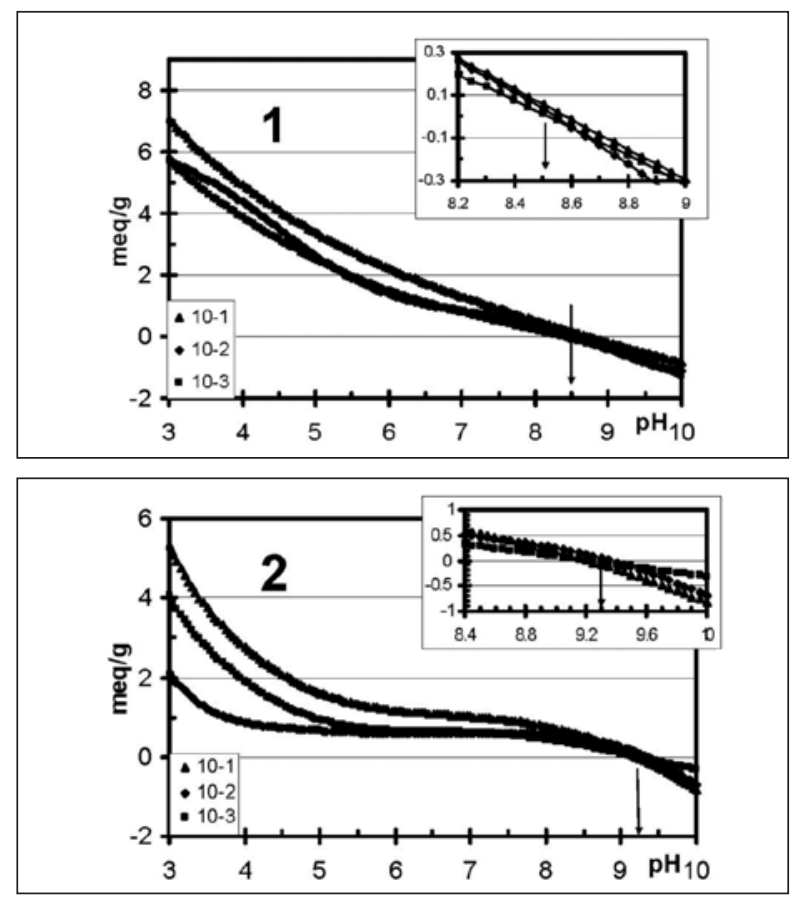

Figure 4. Potentiometric titration curves for Samples 1 and $2 . \mathrm{KCl}$ was the support electrolyte of each curve and the concentration is indicated in Moles. The arrow indicates the $\mathrm{pH}$ of $\mathrm{PZC}$ (curves cross point).
The IEP value was carried out with a curve that fit the obtained experimental data [18], being the correlation coefficient in both curves upper than $\mathrm{R} 2=0.89$. The method error $( \pm 0.3 \mathrm{pH})$ doesn't allow to evidence the existence of significant differences between the IEP values obtained for both samples (IEPpH $=9.0$ and 9.3).

Figure 4 shows the potentiometric titration curves for both samples.

The PZC values, $\mathrm{pH} 8.5$ and 9.3, obtained from titration curves show difference between both samples (method error $\mathrm{pH} \pm 0.2$ ).

The difference of $\mathrm{pH}$ values 9.0 and 8.5 obtained for IEP and PZC, respectively, for Sample 1 indicates the existence of specific adsorption or interactions, which generates coatings among the constituents of the sample. On the other hand, the coincidence between the $\mathrm{pH}$ values of IEP and PZC ( $\mathrm{pH}=9.3)$ for Sample 2 evidences the absence of specific adsorption, due to the elimination of slimes in the hydrocyclon.

\section{CONCLUSIONS}

Hydrocycloning of borates from Sijes District, Salta, Argentina, eliminates the presence of small slimes, among them smectites. It was determined by XRD quantitative method, which generates a specific surface decrease in the purified sample.

The difference found between PZC and IEP values obtained for Sample 1 (without desliming), in coincidence with the observations from electronic microscopy, indicates the existence of associations among particles of colemanite, hydroboracite and slimes, which was eliminated in Sample 2 by hydrocycloning.

\section{ACKNOWLEDGEMENT}

The authors thank PhD S. Conconi and Mr. O. Gamboni, for their cooperation in the quantitative mineralogical determination by Rietveld method and the determination of specific surface, respectively. 


\section{REFERENCES}

[1] H.R. Flores, P.D. Villagrán. "Hidroboracita: Separación magnética de impurezas". INBEMI. Informe reservado. Argentina. 1996.

[2] H.R. Flores, P.D. Villagrán, O. Capalbi. "Processing of ulexite ores". Proc. 5th Southern Hemisphere Meeting on Mineral Processing, pp. 69-72. Buenos Aires, Argentina. 1997.

[3] H.R. Flores, L.E. Mattenella, S.K. Valdez. "Propiedades físicas, fisicoquímicas y químicas de boratos de la Puna". Actas VI. Jornadas Argentinas de Tratamiento de Minerales. Salta, Argentina, pp. 31-7. 2000.

[4] H.R. Flores, L.E. Mattenella, S.K. Valdez. "Physicochemical properties of borates from the south American Puna". Proc. VI SHMMT/XVIII ENTMME. Rio de Janeiro, Brasil, pp. 9-14. 2001.

[5] H.R. Flores. "El Beneficio de los Boratos". Editorial Crisol. Salta, Argentina, Vol. 98, pp. 24-30, 104, 146. 2004.

[6] W. Vickery and P. Nancarrow. "Borate raw materials for ceramic frit industry". Key Engineering Materials. Vol. 132-136, pp. 2172-75. 1997.

[7] S. Stefanov. "Applications of borate compounds for the preparation of ceramic glazes". Glass Tecnol. Vol. $41 \mathrm{~N}^{\mathrm{o}}$ 6, pp. 193-6. 2000.

[8] M.S. Celik, S. Atak, G. Onal. "Flotation of boron minerals". Minerals \& Metallurgical Processing, pp. 149-153. 1993.

[9] M.S. Celik, R. Bulut. "Mechanism of selective flotation of sodium-calcium borates with anionic and cationic collectors". Separation science and technology. Vol. $31 \mathrm{~N}^{\circ} 13$, pp. 1817-1829, 1996.

[10] M. Hancer and M. S. Celik. "Flotation mechanisms of boron minerals". Sep. Sci. \& Tech. Vol. $28 \mathrm{~N}^{\circ}$ 9, pp. 1708-1714. 1993.

[11] D.E. Garrett. Borates Handbook of deposits. Processing. Properties and uses. Academic Press Oxford. 1998.
[12] L.E. Mattenella. "Flotación por espuma de boratos del noroeste argentino". Editorial Gótica. Salta, Argentina. 2001.

[13] J.I. Goldstein and H. Yakowitz. Practical Scanning Electron Microscopy: Electron and Ion Microbe Analysis, Plenum Press, New York and London, pp. 26-30. 1975.

[14] H.M. Rietveld. "A profile refinement method for nuclear and magnetic structures". J. Appl. Crystal. Vol. 2, pp. 65-71. 1969.

[15] J. Rodriguez-Caravajal. "Fullprof. A program for Rietveld Refinement and Pattern Matching Analysis". Abstracts XV of Congress of the IUCr. Toulouse, France, pp. 127. 1990.

[16] International Centre for Diffraction Data. Mineral Powder Diffraction Databook, USA. 1993.

[17] S. Brunnauer, P. H. Emmett and E. Teller "Adsorption of gases in multimolecular layers". J. Amer. Chem. Soc. Vol. 60, pp. 309-319. 1938.

[18] M. Tschapek, R.M. Torres Sánchez and C. Wasowski. "Handy methods for determining the IEP of soils". Z. Pfl. und Bodenkunde. Vol. 152, pp. 73-76. 1989.

[19] L. Blok and P. De Bruyn. "The ionic double layer at the $\mathrm{ZnO}$ solution interface I. The experimental, PZC”. J. Coll. Interf. Sci. Vol. 32, pp. 518-25. 1970.

[20] R.D. Bonetto, P. Zalba, M.S. Conconi, and M. Manassero. "The Rietveld method applied to quantitative phase analysis of minerals containing disordered structures". Rev. Geol. de Chile, Vol. $30 \mathrm{~N}^{\mathrm{o}}$ 1, pp. 103-115. 2003.

[21] S. Gregg and K.S. Sing. "Adsorption surface area and porosity". $2^{\text {nd }}$ edition. Acad. Press. London. 1982.

[22] L. Clausen and I. Fabricius. "BET Measurements, outgasing of minerals". J. Coll. Interf. Sci., Vol. 227, pp. 7-15. 2000.

[23] M. Escudey and G. Galindo. "Effect of iron oxide coatings on electrophoretic mobility and dispersion of allophone". J. Colloid and Interf. Sci. Vol. 93, pp. $78-83.1983$. 
[24] J. Davies, J. Leckie. "Surface ionization and complexation at the oxide water interface: $3^{\text {rd }}$. adsorption of anions". J. Coll. Interf. Sci. Vol. 74, pp. 32-43. 1980.

[25] A. Breeuwsma, H. Lyklema. "Physical and Chemical adsorption of ions in the electrical double layer on hematite". J.J. Colloid Interface Sci. Vol. 43, pp. 437-448. 1973.
[26] J. Lyklema. "Fundamentals of Interface and Colloid Sci. Vol. II, Chap. 3. Acad. Press, London, pp. 107. 1995.

[27] S. L. Swarten-Allen and E. Matijevic. "Surface and colloid chem. of clays". Chemical Rev. Vol. $74 \mathrm{~N}^{\circ}$ 3, pp. 385-390. 1974. 